\title{
MEMBANGUN ENTREPRENEURSHIP DALAM PERSPEKTIF EKONOMI SYARIAH
}

\author{
Yunus Mustaqim \\ Universitas Muhammadiyah Kudus \\ Email korespondensi: yunusmustaqim@umkudus.ac.id
}

\begin{abstract}
Efforts to grow or build entrepreneurship these days are no longer the only thing that need to be done, but it is already a matter that must be or must be done by everyone. This obligation is caused more by an urgent need for someone to get out of economic weakness. This study analyzes about building entrepreneurship in a sharia economic perspective. This research method uses library research with qualitative descriptive data analysis. The results of this study note that building entrepreneurship in the perspective of Islamic economics is to develop a character that is disciplined, independent, realistic, committed, honest, and productive, to realize a benefit that can bring blessings and continue to run its business with attention to the balance of world life and the hereafter. With these characters will have an impact on entrepreneur to always maintain his business well and not to do a business activity that is detrimental to others, such as destroying other people's businesses in a false manner. So that later will reach the goal of life, namely the goal to achieve fallah and maslahah. An entrepreneur thinks of long-term good fortune both the world and the hereafter and does not only look at the material but also looks at the spiritual. Entrepreneur will feel achieved and fulfilled the needs of life in a balanced way between the world and the hereafter.
\end{abstract}

Keywords: Entrepreneurship, Business, Islamic Economic

\section{A. PENDAHULUAN}

Peranan entrepreneur bagi negara adalah membuka jenis usaha baru dan lapangan kerja yang baru. Entrepreneur merupakan proses untuk melakukan pengidentifikasian, pengembangan, dan serta membawa pandangan ke depan dalam kehidupan. Artinya entrepreneur memiliki peranan penting dengan kemampuan untuk menciptakan dan menyediakan produk yang memiliki nilai tambah melalui keberanian mengambil resiko, kreativitas dan inovasi dalam usaha serta mampu menata dengan baik dalam mencari dan membaca peluang yang ada dalam pasar.

Entrepreneur memiliki peran yang signifikan dalam pembangunan ekonomi suatu negara. Sebab entrepreneur memberikan banyak perubahan dalam pembangunan suatu negara, seperti Amerika Serikat yang memiliki 3,5\% wirausahaan dari total jumlah penduduknya. Sekarang ini banyak kesempatan bagi setiap orang untuk berwirausaha dengan cara melihat berbagai peluang bisnis yang ada. Kewirausahaan memberikan pengembangan karir dalam pribadi seseorang yang nantinya dapat memberikan kesejahteraan masyarakat 
berupa pekerjaan dan serta memberikan banyak pilihan bagi konsumen untuk memanfaatkan barang dan jasa, baik skala nasional maupun internasional. Hal ini juga telah dilakukan oleh Pemerintah Indonesia dengan membuat terobosan entrepreneur millennial (era 4.0) agar para kaum millennial memiliki pendapatan serta dapat memberikan perubahan dalam diri sendiri dan buat negara pada umumnya. Ini sejalan dengan Intruksi Presiden RI No. 4 Tahun 1995 bahwa kewirausahaan adalah semangat, sikap, perilaku, dan kemampuan seseorang dalam menangani usaha atau kegiatan yang mengarah pada upaya mencari, menciptakan, menerapkan cara kerja, teknologi dan produk baru dengan meningkatkan efisiensi dalam rangka memberikan pelayanan yang lebih baik dan memperoleh keuntungan yang lebih besar.

Dalam melakukan entrepreneur, seorang wirausaha perlu memperhatikan beberapa hal yang tidak menggangu dalam aktivitas usahanya, yaitu: a) Seni bernegosiasi; artinya dalam berwirausaha haruslah menggunakan bahasa yang mudah dipahami dan dapat dimengerti oleh siapapun dan serta jangan sampai mengatakan kata "tidak" dalam melakukan negosiasi dengan siapapun saat transaksi atau juga saat menjalin kerjsama. b) Akumulasi pengeluaranpengeluaran kecil; artinya seorang entrepreneur harus memperhatikan sekecil apapun dalam aktivitas usahanya. Seperti biaya-biaya kecil dalam usaha, tunggakan tagihan ataupun yang lainnya. Karena pengeluaran yang kecil ini, jika diakumulasikan akan memberikan beban usaha dengan tagihan besar. c) Merencanakan keuangan; artinya seorang wirausaha harus bisa melihat kondisi keuangan agar nantinya antara pendapatan dan pengeluaran bias seimbang. Dengan adanya keseimbangan tersebut . dapat memberikan rasa aman bagi keuangan dalam usaha. Maka, perlu adanya perencanaan keuangan yang matang untuk dapat menjalankan roda usahanya dengan baik. d) Memahami pajak; artinya seorang wirausaha dalam membangun usaha harus memiliki Nomor Pokok Wajib Pajak (NPWB) serta pajak bagi usaha agar nantinya dalam pengembangan usahanya lebih mudah untuk mendapatkan berbagai bantuan ataupun yang lainnya. Dan serta dapat memberikan kemudahan bagi seorang entrepreneur dalam mengetahui perkembangan hasil pendapatan bersih yang didapatkan selama satu tahun. e) Perekrutan dan pelatihan kerja; artinya seorang wirausaha harus mengikuti pelatihan-pelatihan guna meningkatkan suatu kreativitas dan inovatif dalam mengembangkan usahanya, sehingga nantinya dalam pengembangan usahanya dapa melakukan perekrutan yang dapa diandalkan serta memberikan kesempatan-kesempatan bagi karyawannya untuk mengikuti kegiatan pelatihan.

Melihat hal tersebut, maka perlu membangun entrepreneurship pada diri seseorang untuk memiliki usaha yang dapat membantu dalam kehidupan perekonomiannya (micro- 
economy) dan juga tidak akan tertinggal dengan negara-negara lain dalam meningkatkan perekonomian negara (macro-economy). Untuk mewujudkan hal itu, satu hal yang harus disadari adalah bahwa untuk menjadi seorang wirausahawan yang baik kata kuncinya adalah praktek atau melaksanakan sesuatu mulai dari hal yang terkecil dengan pandangan yang positif dan penuh dengan keberanian. Cepat atau lambat seharusnya waktu dapat mengajarkan diri ini bagaimana untuk melakukan sesuatu yang terbaik dalam hidup ini tanpa harus membuang percuma waktu dengan hanya mengeluh dan menyalahkan orang lain atas ketidakberdayaan diri ini. Selain itu, seorang wirausahawan yang baik harus memiliki jiwa disiplin, jujur, komitmen dan lain sebagainya.

Ketika seorang wirausahaan menanamkan diri dalam jiwanya mengenai jujur (Qs. AlMuthaffifi, 83: 1-3), mandiri, komitmen (Qs. Fushshilat, 41: 30) dengan baik dan sungguhsungguh itu sudah melakukan tuntunan ajaran Islam. Artinya, dalam berentrepreneur diperlukan suatu kejujuran yang berbicara terbuka dan apa adanya saat menjualkan atau menawarkan suatu hasil produknya serta seorang entrepreneur juga harus memiliki kemandirian yang baik, dimana tidak boleh menggantungkan dari orang lain saat mengalami suatu permasalahan dalam usahanya. Hal ini sesuai dengan penelitian yang dilakukan oleh Darwis (2016) dijelaskan bahwa entrepreneurship yang terdapat dalam Islam yaitu: 1) aktif; dimana Islam mendorong umatnya agar bersifat aktif dan memiliki etos kerja yang tinggi, 2) produktif; dimana entrepreneur memiliki kemampuan dan kemauan untuk berkompetensi dengan sportif, 3) kreatif dan inovatif; dimana seorang entrepreneur selalu melihat segala sesuatu dengan cara berbeda dan baru dan serta 4) kalkulatif; dimana seorang entrepreneur berani mengambil resiko.

Penelitian lain juga dilakukan oleh Zulfiria dan Arif (2018) yang mengatakan bahwa entrepreneurship terdapat dalam Al-Qur'an sebagai landasan bagi etos kerja keras yang perlu dipegang oleh umat Islam, yaitu harus produktif, aktif, integritas dan tawakal. Berdasarkan penelitian terdahulu, maka Indonesia sebagai negara muslim, menjadi sebuah pertanyaan sejauh mana pengaruh nilai-nilai keagamaan (syariah), khususnya Islam, terhadap kultur masyarakat Indonesia untuk berwirausaha. Apakah nilai-nilai keagamaan (syariah) mendorong seseorang untuk memiliki nilai-nilai kewirausahaan dan serta mengimplementasikannya dalam masalah perekonomian yang tidak bisa lepas dari kehidupan.

Berbeda dengan penelitian yang dilakukan oleh Darwis (2016) bahwa hasil penelitian tersebut adalah dalam upaya pembagunan muslim entrepreneurship dilakukan dengan cara 
membangun karakter, membentuk kepercayaan diri, menumbuh kembangkan semangat kerja keras atau keinginan selalu beraktivitas dan pengendalian diri, serta memberikan keyakinan yang dalam dan istiqomah dalam ketelitian, kecermatan dan perkembangan pola pikir yang kreatif serta problem solving melalui pendidikan.

Untuk menciptakan seorang wirausahawan tidaklah mudah. Sebab masyarakat Indonesia cenderung memilih pekerjaan sebagai karyawan ataupun pegawai, baik negeri/swasta. Secara tidak langsung, pendidikan formal maupun non formal di Indonesia masih belum berorientasi pada entrepreneurship. Hal ini dikarenakan wirausaha belum menjadi alternatif pilihan negara dalam memecahkan krisis multidimensional yang melanda Indonesia walaupun saat ini pemerintah sudah merencanakan pengembangan sektor usaha kecil menengah. Akan, tetapi jika mau mengikuti konsep yang sesuai dengan tuntunan ajaran Islam sebagai suatu agama yang memang hadir untuk menghormati umat manusia di muka bumi ini, tentu bangsa Indonesia akan mampu menjawab seluruh problem kesejahteraan dengan segera menciptakan entrepreneursip berbasis ekonomi syariah.

Berdasarkan uraian di atas, terdapat gap research bahwa dalam menanamkan nilai-nilai keagamaan pada entrepreneur tidak hanya bertumpu pada produktif, aktif, integritas, tawakal, kreatif dan inovatif serta kalkulaif. Namun, bisa hal lain yang dapat ditanamkan dalam entrepreneur kaitannya dengan ekonomi syariah. Maka untuk membangun entrepreneur yang baik dalam pandangan ekonomi syariah yaitu saat menjalankan usaha tidak melakukan kegiatan usaha yang merugikan orang lain serta tidak melakukan penjualan barang haram yang dilarang oleh agama dan negara dan lainnya.

Melihat uraian di atas, maka rumusan masalah penelitian yang dapat diidentifikasi yaitu bagaimana menanamkan nilai- nilai keagamaan pada entrepreneurship dalam perspektif ekonomi syariah serta tujuan yang diharapkan dalam penelitian ini adalah untuk menganalisis entrepreneurship dalam perspektif ekonomi syariah.

\section{B. TELAAH PUSTAKA}

\section{Entrepreneurship dalam Islam}

Bekerja merupakan salah satu sebab pokok yang memungkinkan manusia memiliki harta kekayaan. Al-Qur'an juga menyerukan pada semua orang yang memiliki kemampuan fisik untuk bekerja dalam usaha mencari sarana hidup untuk dirinya sendiri, tak seorangpun dalam situasi normal, dibolehkan untuk meminta-minta atau menjadi beban kerabat dan negara sekalipun. Al-Qur'an sangat menghargai mereka yang berjuang untuk mencapai dan 
memperoleh karunia (segala macam sarana kehidupan) Allah (Mustaq, 2010). Dalam pandangan Al-Qur'an juga kerja dan amal adalah yang menentukan posisi dan status seseorang dalam kehidupan. Sebagaimana hal tersebut diungkap dalam Al-Qur'an Sura AlAn'aam aya 132:

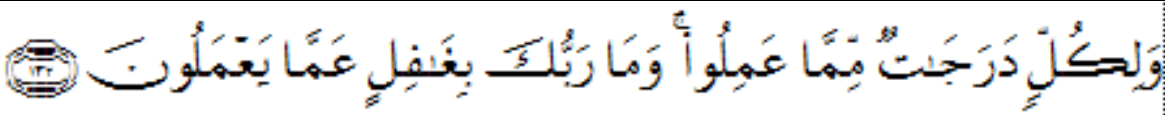

Artinya:

"Dan masing-masing orang memperoleh derajat-derajat (seimbang) dengan apa yang dikerjakannya. dan Tuhanmu tidak lengah dari apa yang mereka kerjakan.” (Qs. Al-Anam: 132)

Bekerja adalah sebagian ibadah dan jihad jika bersikap konsisten terhadap peraturan Allah SWT, suci niatnya dan tidak melupakan Allah SWT. Menurut Islam pada hakekatnya setiap muslim diminta untuk bekerja meskipun hasilnya belum dapat dimanfaatkan olehnya dan orang lain. Seseorang wajib bekerja karena bekerja merupakan hak Allah SWT dan salah satu cara mendekatkan diri kepada Allah SWT (al-Qordhawi, 2019). Dengan bekerja, maka akan memberikan perubahan dalam dirinya dari segala aspek, hal ini sesuai dengan firman Allah SWT:

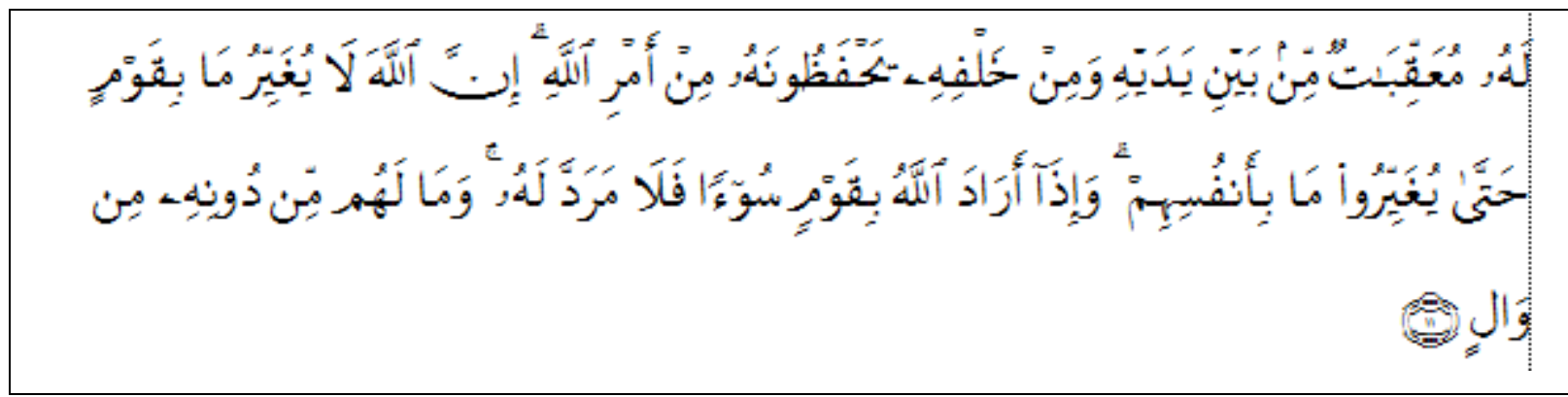

Artinya:

"Bagi manusia ada malaikat-malaikat yang selalu mengikutinya bergiliran, di muka dan di belakangnya, mereka menjaganya atas perintah Allah. Sesungguhnya Allah tidak merobah Keadaan sesuatu kaum sehingga mereka merobah keadaan yang ada pada diri mereka sendiri. dan apabila Allah menghendaki keburukan terhadap sesuatu kaum, maka tak ada yang dapat menolaknya; dan sekali-kali tak ada pelindung bagi mereka selain Dia." (Qs. Ar-Ra'd:11)

Melihat ayat di atas, dapat dipahami bahwa ayat ini bersifat 'aam (umum) yakni siapa saja yang mencapai kemajuan dan kejayaan bila mereka sudah merubah sebab-sebab kemundurannya yang diawali dengan merumuskan konsepsi kebangkitan. Atau dengan kata 
lain bahwa seseorang bisa berubah dan bangkit apabila dirinya sendiri merubah dengan baik dan bertanggung jawab apa yang dikerjakannya. Oleh karena itu, tujuan bekerja dalam Islam adalah tidak hanya menghasilkan harta, tetapi juga bernilai berkah serta sebagai media untuk memakmurkan bumi. Sebagaimana firman Allah SWT:

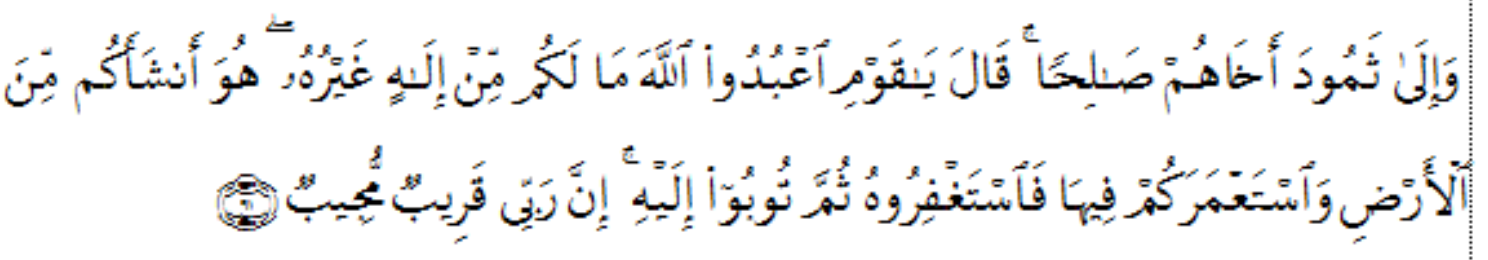

Artinya:

"Dan kepada Tsamud (kami utus) saudara mereka shaleh. Shaleh berkata: "Hai kaumku, sembahlah Allah, sekali-kali tidak ada bagimu Tuhan selain Dia. Dia telah menciptakan kamu dari bumi (tanah) dan menjadikan kamu pemakmurnya, karena itu mohonlah ampunan-Nya, kemudian bertobatlah kepada-Nya, Sesungguhnya Tuhanku Amat dekat (rahmat-Nya) lagi memperkenankan (doa hamba-Nya)." (Qs. Huud:61)

Berdasarkan ayat di atas, dapat dipahami bahwa bekerja merupakan amanah yang diberikan Allah kepada manusia agar alam semesta yang luas terbentang ini dapat digarap dan diolah dengan tujuan kemakmuran dan kesejahteraan umat. Selain itu, dalam rangka pemakmuran bumi Allah SWT, artinya seseorang yang memiliki tanah agar memanfaatkan tanahnya dengan baik (produktif) atau jangan sampai membiarkan tanah itu terlantar dan tidak diproduktifkan atau dimanfaatkan.

Melihat uraian di atas, dapat diketahui bahwa entrepreneurship dalam Islam pada dunia akademik telah menjadi istilah baku dalam studi-studi economics religion terhadap keyakinan sesorang kepada Dzat Yang Maha Tinggi dalam pengaruhnya terhadap kesuksesan bisnis. Menurut Slaughter (2010) bahwa secara universal, entrepreneur dalam Islam bermakna komitmen pada 6 prinsip teologi:

(1) The lordship principle: a clear focus on Jesus Christ as the object of faith; (2) The biblical principle: scriptural truth as the primary source for what we belief and do; (3) The liturgical principle: discovery of new worship forms; (4) The covenant principle: commitment to the integrity of membership; (5) The priesthood principle: equipping the laity for ministry; (6) The leadership principle: spiritual entrepreneurship.

Melihat pendapat di atas, mengenai teori entrepreneurship diaplikasikan dalam konteks Islam, maka secara universal bermakna bahwa kewirausahaan yang berkomitmen atau berdasarkan pada prinsip ketuhanan, prinsip kitabiah (nilai-nilai Al-Qur'an), prinsip 
peribadatan, prinsip perjanjian, prinsip imamah (kesiapan untuk melayani) dan prinsip kepemimpinan. Menurut Suherman (2012), entrepreneur dalam Islam adalah pengelolaan kegiatan keagamaan dengan pola dan gaya entrepreneur yang memiliki landasan agama yang kuat, keimanan yang kokoh dan ketaqwaan yang tinggi.

Berdasarkan uraian di atas dapat disimpulkan bahwa entrepreneurship dalam Islam adalah berbisnis dalam urusan duniawi yang sangat berhubungan erat dengan akhirat dan berbisnis harus tetap mengutamakan yang namanya rambu-rambu agama.

\section{Karakerisik Entrepreneurship}

Seorang wirausahawan haruslah seorang yang mampu melihat kedepan. Melihat kedepan dengan berfikir penuh perhitungan mencari pilihan dari berbagai alternatif masalah dan pemecahnnya. Entrepreneurship mempunyai potensi untuk memberikan kontribusi yang banyak kepada masyarakat, para peneliti mencoba menganalisis kepribadian, keterampilan, dan sikap mereka. Seperti diketahui bahwa wirausahawan bersifat kompleks, dan tidak ada satu teori pun yang dapat menjelaskan semua tingkah laku mereka sehingga karakteristik entrepreneurship adalah sebagai berikut (Asmani, 2011):

a. Kebutuhan untuk berprestasi. Wirausahawan mempunyai kebutuhan untuk berprestasi.

b. Letak kendali. Ini adalah ide bahwa individu mengendalikan hidup mereka sendiri, bukan keberuntungan atau nasib. Wirausahawan atau manajer suka berpikir mereka menarik tali mereka sendiri.

c. Toleransi terhadap resiko. Wirausahawan yang bersedia mengambil resiko yang sedang tampaknya memperoleh hasil yang lebih besar dalam aset daripada wirausahawan yang tidak mau mengambil resiko.

d. Toleransi terhadap keragu-raguan sampai batas tertentu. Setiap manajer memerlukan ini, karena banyak keputusan harus dibuat dengan informasi yang tidak lengkap atau tidak jelas. Tetapi wirausahawan lebih banyak menghadapi keragu- raguan, karena mereka melakukan sesuatu untuk pertama kalinya bahwa pernah ada orang lain yang melakukan dank arena mereka mempertarukan mata pencahariannya.

e. Tingkah laku. Ini mengacu pada dorongan untuk melakukan lebih banyak dengan waktu yang lebih sedikit dan bila perlu walaupun ditantang oleh orang lain

Melihat uraian di atas, dapat dipahami bahwa karakteristik entrepreneurship yang ada pada diri seseorang dalam menjalankan usaha adalah adanya kebutuhan untuk berprestasi, kendali, toleransi terhadap resiko, toleransi terhadap keragu-raguan dan adanya tingkah laku. 
Entrepreneur merupakan keahlian seseorang dalam menghadapi resiko dimasa mendatang dan tumbuh untuk mendapatkan profit dengan menggunakan seluruh sumber daya yang dimiliki sehingga mengalami peningkatan terhadap usaha tersebut. Oleh karenanya, entrepreneur mempunyai enam karakteristik, yaitu (Suryana, 2017):

a. Memiliki kepercayaan diri yang kuat, ketidakbergantungan terhadap orang lain.

b. Berorientasi pada tugas dan hasil yang baik.

c. Berani mengambil risiko yang wajar dan serta menyukai tantangan.

d. Memiliki jiwa kepemimpinan, keterbukaan serta mudah beradaptasi dengan orang lain.

e. Membuat inovasi, kreatif dan fleksibel dalam kapitalisasi bisnis.

f. Memiliki visi dan perspektif pada masa depan.

Berdasarkan uraian di atas, dapat dipahami bahwa seorang wirausahawan harus memiliki karakter yang disiplin, mandiri, realistis, komitmen, jujur, kreatif dan inovatif serta istiqomah untuk mewujudkan suatu keuntungan yang dapat membawa keberkahan dan tetap menjalani usahanya dengan memperhatikan kesimbangan antara dunia dan akhirat.

\section{METODOLOGI PENELITIAN}

Metode penelitian mengemukakan secara teknis tentang metode-metode yang digunakan dalam penelitian. Penelitian ini merupakan kepustakaan (library research) yang mengandalkan data-data dari perpustakaan, sehingga bentuk penelitian ini bersifat deskriptif kualitatif. Studi kepustakaan melalui buku-buku dan jumal-jumal ilmiah terkait, seperti Slaughter (2010) dengan judul buku 6 Principles for Risking Renewal Spiritual Entrepreneurs, Suryana (2017) dengan judul buku Kewirausahaan, Yusuf al-Qardhawi (2019) dengan judul buku Norma dan Etika Ekonomi Islam, Hendro (2010) dengan judul Kewirausahaan dan lain sebagainya serta beberapa jurnal yaitu Darwis (2017) dengan judul penelitian Entrepreneurship dalam Perspektif Islam; Meneguhkan Paradigma Pertautan Agama dengan Ekonomi, Zulfiria dan Arif (2018) dengan judul penelitian Membangun Kewirausahaan (Entrepreneurship) Qur'ani di Perguruan Tinggi, Darwis (2016) dengan judul penelitian Pendekatan Syariah dalam Upaya Membangun Karakter Jiwa Entrepreneurship dan lain sebagainya.

Untuk memperoleh data dalam proses penelitian dapat mengandalkan dokumentasi dari media dan teori dari berbagai literatur, sehingga objek penelitian ini adalah dokumen, informasi media dan literatur yang membahas mengenai membangun entrepreneurship dalam perspektif ekonomi syariah. Jenis data yang digunakan penelitian ini adalah data sekunder 
yang mana memanfaatkan dari data dokumentasi dan arsip-arsip lainnya yang terkait dengan permasalahan yang peneliti teliti (Moleong, 2018). Pengumpulan data yang digunakan adalah dokumentasi serta referensi. Untuk menganalisis data menggunakan analisis deskriptif kualitatif yaitu suatu cara yang digunakan untuk menggambarkan atau menganalisis suatu hasil penelitian tetapi tidak digunakan untuk membuat kesimpulan yang lebih luas dengan metode deduktif dan induktif.

\section{HASIL DAN PEMBAHASAN}

\section{Analisa Entrepreneurship dalam Perspektif Ekonomi Syariah}

Allah SWT menciptakan manusia sebagai makhluk yang paling mulia, paling sempurna, dan karena itulah manusia diberi tugas sebagai khalifah di muka bumi ini. Dengan kelebihan akal pikirannya manusia mengatur dan memberdayakan sumber daya alam lainnya untuk memperoleh manfaat dan mewujudkan kehidupan sejahtera. Untuk menjadi entrepreneur tidak hanya semata-mata mencari kekayaan materi tanpa memedulikan nilainilai dan etika dalam berbisnis. Orientasinya hanya sekedar menumpuk kekayaan dan terjebak dengan kehidupan yang hedonis. Hal ini jelas berdampak pada kehancuran bisnisnya sendiri. Maka, perlu adanya pandangan secara Islam (syariah) agar seorang entrepreneur memiliki karakter dalam membangun usaha dengan baik. Menurut pandangan penulis entrepreneurship dalam perspektif ekonomi syariah dilihat dari karakter di bawah ini:

\section{a. Disiplin}

Disiplin merupakan latihan untuk mengendalikan diri, karakter, atau keadaan yang tertib dan efisien (Wiyani, 2013). Artinya, disiplin memberikan manfaat bagi seseorang untuk bisa mengendalikan diri dalam melakukan kegiatan yang sesuai dengan waktunya, memberikan gambaran karakter yang tepat pada waktunya saat menyelesaikan pekerjaan serta mentaati semua aturan secara efisien sesuai dengan situasi dan kondisi. Jika disiplin ditanamkan secara terus menerus maka disiplin tersebut akan menjadi kebiasaan bagi seseorang. Orang-orang yang berhasil dalam bidangnya masing-masing umumnya mempunyai kedisiplinan yang tinggi. Sebaliknya orang yang gagal, umumnya tidak disiplin (Imron, 2012). Salah satunya adalah sebagai seorang wirausahawan.

Seorang wirausahawan harus memiliki kedisiplinan yang tinggi. Arti harus memiliki ketepatan komitmen wirausahawan terhadap tugas dan pekerjaannya. Ketepatan yang dimaksud bersifat menyeluruh, yaitu ketepatan terhadap waktu, kualitas pekerjaan, sistem kerja dan sebagainya. Sebab disiplin adalah kunci sukses yang akan menumbuhkan sifat yang 
teguh dalam memegang prinsip seseorang dalam kehidupan, baik secara pribadi, masyarakat, berbangsa maupun secara luas.

Allah berfirman dalam surat Al-'Ashr ayat 1-3:

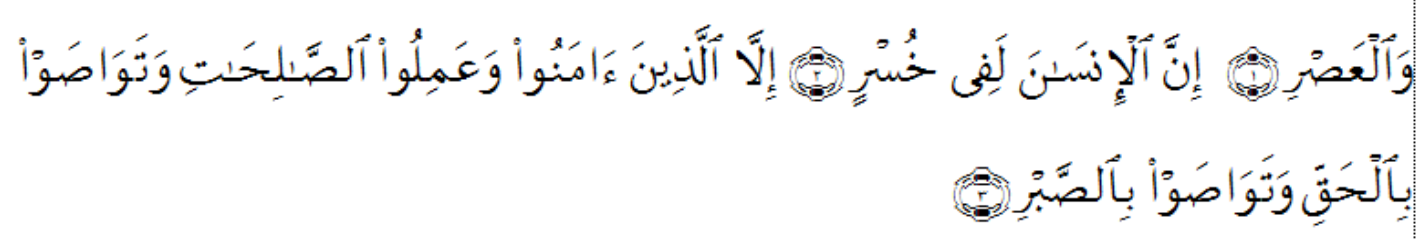

Artinya:

1. Demi masa.

2. Sesungguhnya manusia itu benar-benar dalam kerugian,

3. Kecuali orang-orang yang beriman dan mengerjakan amal saleh dan nasehat menasehati supaya mentaati kebenaran dan nasehat menasehati supaya menetapi kesabaran.” (Qs. Al-‘Ashr:1-3)

Berdasarkan ayat di atas, dapat dipahami bahwa disiplin sangatlah penting dalam diri pribadi maupun kehidupan seseorang, sebab ketika kurang disiplin dalam melakukan hal apapun maka kerugian yang akan dirasakan. Untuk itu, dalam konteks entrepreneurship, ketepatan terhadap waktu sangat berarti sekali karena ini akan memberikan dampak dalam roda usahanya. Sifat sering menunda pekerjaan dengan berbagai macam alasan, adalah kendala yang dapat menghambat seorang wirausahawan meraih keberhasilan.

b. Mandiri

Mandiri merupakan suatu kondisi dimana seseorang memiliki hasrat untuk maju demi kebaikannya diri sendiri serta mampu mengambil keputusan dan inisiatif untuk mengatasi masalah yang dihadapinya (Desmita, 2011). Artinya seseorang yang mandiri memiliki perilaku mampu berinisiatif, mampu mengatasi masalah, mempunyai rasa percaya diri dan serta dapat melakukan sesuatu tanpa melibatkan bantuan orang lain. Setiap yang merasa dirinya ingin sukses, maka memerlukan sikap mandiri, karena dengan kemandirian akan meraih sebuah keberhasilan. Maka sikap mandiri sangat diperlukan oleh seseorang yang ingin berwirausaha.

Seorang wirausaha harus memiliki karakter mandiri, yaitu sikap untuk tidak menggantungkan sesuatu apapun kepada orang lain, seperti pengambilan keputusan, pengelolaan dan lain sebagainya. Seorang yang menjalankan usaha (barang atau jasa) secara pribadi harus mampu hidup mandiri tidak bergantung dengan orang lain, mampu memberikan keputusan terhadap suatu masalah dalam usahanya dalam keadaan apapun. 
Kemandirian merupakan sifat mutlak yang harus dimiliki oleh seorang entrepreneur. Pada prinsipnya seorang entrepreneur harus memiliki sikap mandiri dalam memenuhi kegiatan usahanya. Rasulullah SAW sangat mengajurkan umatnya untuk mandiri secara ekonomi. Dampak kemandirian ini sangat luas. Orang yang hidup mandiri dapat berjalan setengah "terbang" saking ringannya. Karena orang yang hidup mandiri tidak terbebani oleh hutang budi kepada siapa pun. Sebagaimana Sabda Rasulullah SAW:

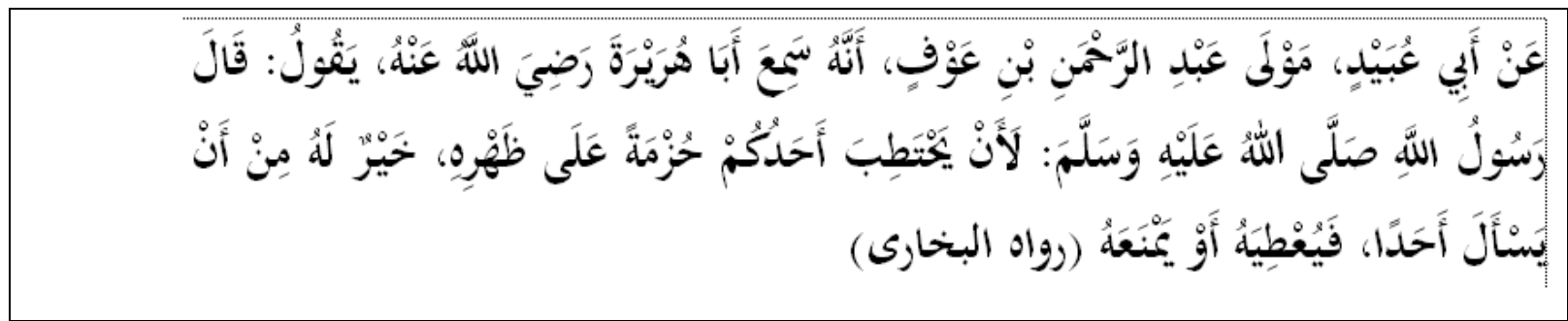

Artinya:

"Dari Abu Ubaid, hamba Abdurrahman bin Auf. Ia mendengar Abu Hurairah berkata, "Rasulullah SAW bersabda, 'Sungguh, pikulan seikat kayu bakar di atas punggung salah seorang kamu (lantas dijual) lebih baik daripada ia meminta-minta kepada orang lain, entah itu diberi atau tidak diberi” (HR. Bukhari).

Berdasarkan hadis di atas, dapat dipahami bahwa terdapat sikap mandiri dalam entrepreneur untuk bertindak bebas, melakukan sesuatu atas dorongan sendiri dan untuk kebutuhan sendiri tanpa melibatkan bantuan orang lain dengan cara berpikir dan bertindak kreatif penuh inisiatif serta mempunyai percaya diri dalam memperoleh kepuasan dari usaha yang dilakukannya.

c. Realistis

Realistis artinya adalah berifat nyata (Departemen Pendidikan dan Kebudayaan, 2012). Artinya bahwa kondisi dimana seseorang merasa sudah tidak harus berpegang terhadap prinsip dasar dan sudah berpiki secara real. Maka dalam dalam berwirausaha harus memiliki cara berpikir yang penuh perhitungan dan sesuai dengan kemampuan, sehingga gagasan atau ide yang akan diajukan bukan hanya mimpi belaka tetapi adalah sebuah kenyataan yang akan dilakukan.

Seorang wirausaha harus memiliki landasan berpikir yang real atau nyata (tidak semu) dalam melakukan tindakan untuk mengembangkan dan memajukan usahanya. Artinya, seorang entrepreneur harus selalu sama apa yang dikatakan dengan perbuatannya. Karena saat sekarang ini banyak seorang wirausahawan yang berpotensi tinggi, namun pada akhirnya mengalami kegagalan hanya karena wirausahawan tersebut tidak realistis, obyektif dan rasionil dalam pengambilan keputusan bisnisnya. Karena itu dibutuhkan kecerdasan dalam 
melakukan seleksi terhadap masukan-masukan atau sumbang saran yang ada keterkaitan erat dengan tingkat keberhasilan usaha yang sedang dirintis.

Jika berbicara dengan realistis tak jauh dari bagaimana cara kita berpikir. Maka berpikir ini kaitannya dengan akal. Akal merupakan daya pikir yang terdapat dalam jiwa manusia, yaitu daya memperoleh pengetahuan dengan memperhatikan alam sekitar. Artinya, orangorang yang tidak berpikir dan menolak untuk menghamba kepada Tuhan, dipandang sebagai mahkluk yang lebih buruk daripada binatang. Sebagaimana firman Allah SWT:

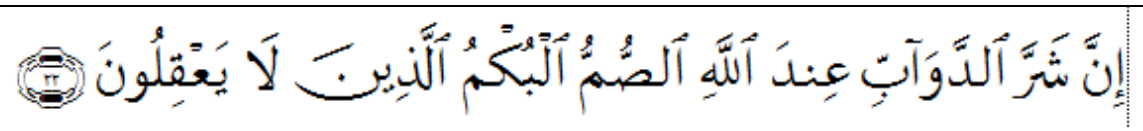

Artinya:

"Sesungguhnya binatang (makhluk) yang seburuk-buruknya pada sisi Allah ialah; orang-orang yang pekak dan tuli yang tidak mengerti apa-apapun.” (Qs. Al-Anfaal:22)

Maksud dari ayat di atas yaitu manusia yang paling buruk di sisi Allah ialah yang tidak mau mendengar, menuturkan dan memahami kebenaran. Untuk itu, dalam Islam, akal dan agama adalah satu hakikat tunggal dan sesuai dengan sebagian riwayat, dimanapun akal berada maka agama akan selalu mendampingi, tidak ada jarak yang terbentang antara iman dan kekufuran kecuali dengan kurangnya akal. Seorang yang berentrepreneur harus mempunyai cara berpikir yang realistis jangan hanya sebuah angan-angan tetapi tidak dilaksanakan.

\section{d. Komitmen}

Hal tak kalah penting dengan karakter-karakter sebelumnya adalah komitmen. Komitmen merupakan perjanjian (keterikatan) untuk melakukan sesuatu (Poerwadarminto, 2011). Artinya, sebuah pengakuan seutuhnya dan sebagai sikap yang sebenarnya yang berasal dari watak yang keluar dari dalam diri seseorang. Apalagi, keterkaitan dengan seorang entrepreneur.

Seorang wirasuaha harus memiliki komitmen dalam dirinya, sebab komitmen merupakan perjanjian untuk melakukan sesuatu. Artinya, komitmen dalam berwirausaha yaitu suatu yang keterikatan dirinya dan keinginan yang kuat untuk mengembangkan dan memajukan usahanya dalam situasi dan kondisi apapun. Biasanya seorang entrepreneur akan mengalami kegundahan sehingga mengakibatkan gagal fokus untuk usaha yang dijalankannya. 
Allah berfirman dalam Al-Qur'an Surat Fushshilat ayat 30:

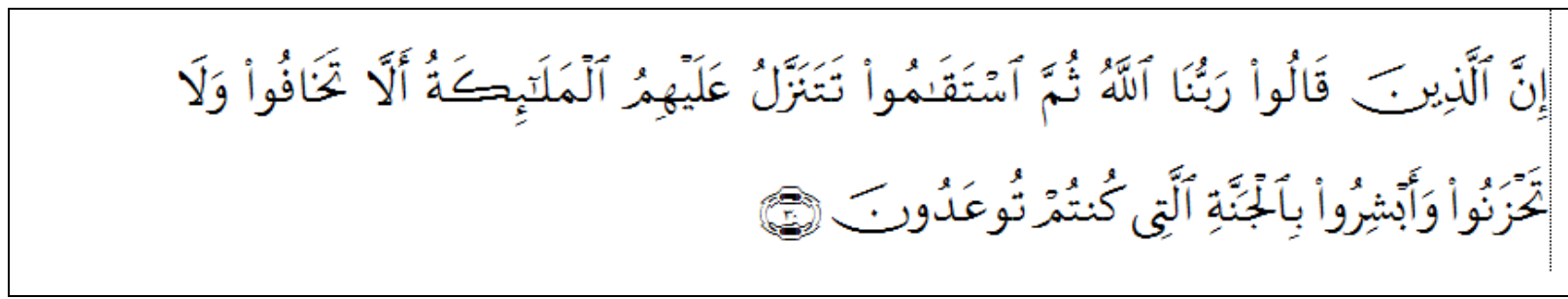

Artinya:

"Sesungguhnya orang-orang yang mengatakan: "Tuhan Kami ialah Allah" kemudian mereka meneguhkan pendirian mereka, maka malaikat akan turun kepada mereka dengan mengatakan: "Janganlah kamu takut dan janganlah merasa sedih; dan gembirakanlah mereka dengan jannah yang telah dijanjikan Allah kepadamu". (Qs. Fushshilat:30)

Melihat ayat di atas dapat diketahui bahwa seseorang yang meneguhkan pendiriannya akan mendapakan kegembiaraan. Sebab dengan adanya komitmen akan mendatangkan pada kelapangan rizeki, diberikan rasa aman, dijauhkan dari kesedihan, diberikan arahan jalan yang baik dan seterusnya. Maka, dalam melaksanakan kegiatannya, seorang entrepreneur harus memiliki komitmen yang jelas, terarah dan bersifat progresif. Komitmen wirausahawan dapat dilakukan seperti pelayanan prima yang berorientasi pada kepuasan konsumen, kualitas produk yang sesuai dengan harga produk yang ditawarkan, penyelesaian bagi masalah konsumen, dan lain sebagainya.

Komitmen yang tinggi perlu dibangun dalam berentrepreneur, sehingga seorang wirausaha diharapkan dapat memiliki kesabaran dan ketabahan dalam berwirausaha, memiliki semangat dan tahan uji dalam menghadapi setiap tantangan yang ada dalam usaha, pantang menyerah dalam keadaan dan situasi apapun dalam usaha, selalu berjuang, bekerja keras, dan rela berkorban demi kemajuan usaha yang dilakukannya (Hendro, 2010).

e. Jujur

Secara harfiah, jujur berarti lurus hati, tidak berbohong, tidak curang. Jujur merupakan nilai penting yang harus dimiliki setiap orang. Jujur tidak hanya diucapkan, tetapi juga harus tercermin dalam perilaku sehari-hari (Naim, 2012). Menurut Mustari (2014) mengatakan bahwa jujur merupakan perilaku yang didasarkan pada upaya menjadikan dirinya sebagai orang yang selalu dapat dipercaya dalam perkataan, tindakan, dan pekerjaan, baik terhadap diri sendiri maupun terhadap pihak lain. Artinya, bahwa kejujuran tidak hanya dilakukan dalam ucapan, akan tetapi berupa tindakan yang positif. Pada dasarnya kejujuran itu adalah alamiah dan sangat diperlukan untuk perkembangan diri dan masyarakat, apalagi berwirausaha. 
Kejujuran sangatlah penting sekali dalam segala aspek kehidupan apapun. Walaupun ada yang mengatakan bahwa jujur sangat sulit untuk dilakukan, namun jika kita bisa melakukan dengan kesadasaran dan kemauan pasti dapat mewujudkan kejujuran dalam aktivitas apapun, salah satunya adalah berwirausaha. Jujur dalam berwirausaha yaitu mampu mengatakan sesuatu apa adanya. Artinya, orang entrepreneur tidak boleh membohongi konsumen atau yang lainnya. Karena kejujuran akan melahirkan sebuah kepercayaan. Jika kepercayaan sudah dirusak dari awal maka akibatnya adalah konsumen tidak akan datang lagi walaupun banyak kreativitas dan inovatif usaha yang dilakukan oleh seorang entrepreneur.

Islam sudah mengajarkan dengan tegas bahwa ketika kita berdagang, maka harus mengutamakan kejujuran. Jangankan menggunakan bahan-bahan yang mengandung zat berbahaya yang dapat merusak kesehatan, mengurangi takaran timbangan pun telah dilarang dalam agama Islam. Sebagaimana firman Allah SWT:

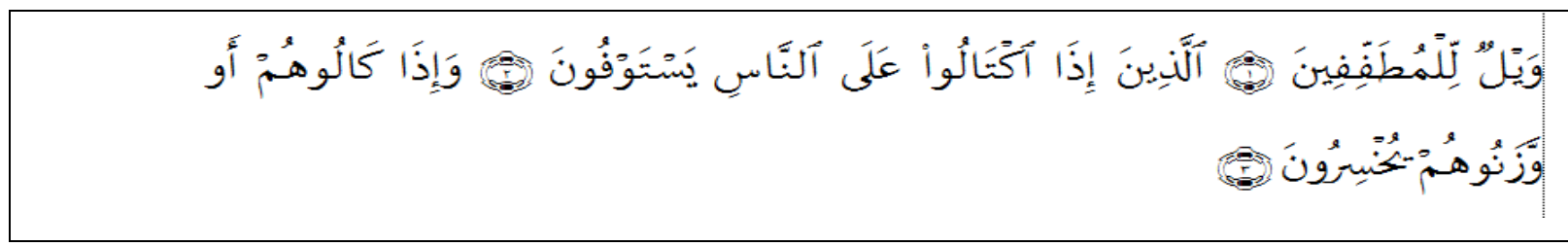

Artinya:

1. Kecelakaan besarlah bagi orang-orang yang curang,

2. (Yaitu) orang-orang yang apabila menerima takaran dari orang lain mereka minta dipenuhi,

3. Dan apabila mereka menakar atau menimbang untuk orang lain, mereka mengurangi." (Al-Muthaffifi:1-3)

Berdasarkan ayat di atas, Islam mengajarkan kepada seorang entrepreneur agar selalu tidak takut akan kehilangan rezeki. Bahwa Allah SWT telah menciptakan langit dan bumi dengan segala isinya dan menciptakan manusia dengan segala keunggulannya, termasuk didalamnya, telah diatur kemudahan rezekinya dengan catatan saat melakukan aktivitas usaha atau bisnisnya harus jujur. Syariat Islam, mengajarkan kepada umatnya untuk berbuat jujur dalam segala keadaan, walaupun secara lahi kejujuran akan merugikan diri sendiri. Allah SWT berfirman: 


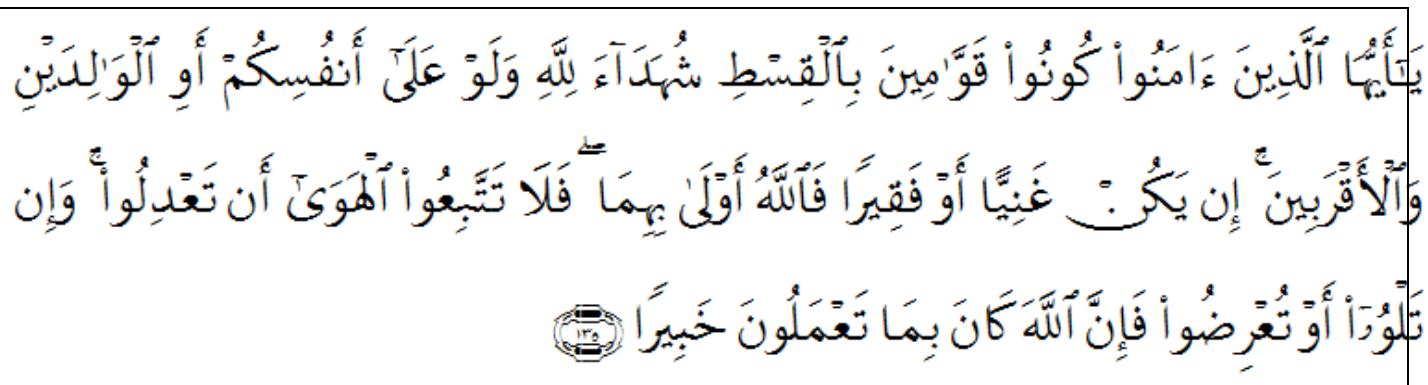

Artinya:

"Wahai orang-orang yang beriman, jadilah kamu orang yang benar-benar penegak keadilan, menjadi saksi karena Allah biarpun terhadap dirimu sendiri atau ibu bapa dan kaum kerabatmu. jika ia kaya ataupun miskin, maka Allah lebih tahu kemaslahatannya. Maka janganlah kamu mengikuti hawa nafsu karena ingin menyimpang dari kebenaran. dan jika kamu memutar balikkan (kata-kata) atau enggan menjadi saksi, maka sesungguhnya Allah adalah Maha mengetahui segala apa yang kamu kerjakan.” (Qs. An-Nisaa:135)

Melihat ayat di atas dapat diketahui bahwa menjadi orang jujur atau bohong merupakan pilihan bagi setiap orang. Bagi orang yang memilih menjalani hidupnya dengan penuh kejujuran dalam segala aspek kehidupannya, maka ia akan memiliki karakter yang baik di mata orang-orang yang mengenalnya. Ketika seseorang selalu berkata jujur dan berbuat benar, maka akan diterima ucapannya di hadapan orang-orang serta disenangi pembicaraanya. Sebaliknya, bagi orang yang selalu berlaku dusta dalam hidupnya, maka ia tidak akan memiliki pandangan yang baik oleh orang-orang di sekitarnya.

\section{f. Produktif}

Produktif merupakan sesuatu hal yang bisa menghasilkan atau mendatangkan keuntungan secara besar atau banyak. Artinya, dalam produktif diperlukan kegiatan produksi. Produksi adalah proses mencari, mengalokasikan dan mengolah sumber daya menjadi output dalam rangka meningkatkan mashlahah bagi manusia. Produksi juga mencakup aspek tujuan kegiatan menghasilkan output serta karakter-karakter yang melekat pada proses dan hasilnya (Pusat Pengkajian dan Pengembangan Ekonomi Islam, 2010).

Seorang entrepreneur adalah sosok individu yang mempunyai karakter produktif. Produktif merupakan rasio antara hasil (output) dengan pengorbanan (biaya) untuk mewujudkan hasil tersebut. Maksud, produktif adalah sikap mental yang berpandangan mutu kehidupan hari ini harus lebih baik dari hari kemarin, dan hari esok harus lebih baik dari hari ini. Produktivitas dengan makna seperti ini dapat diperoleh dari adanya kemampuan dan kemauan untuk berkompetensi, dengan sportif, bebas, dan sikap profesionalisme yang tinggi. 
Jika demikian maka produktivitas semacam ini relevan dengan Al-Qur'an Surah Al-Mulk ayat 2:

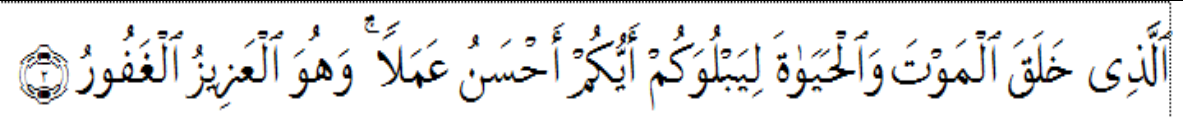

Artinya:

"Dialah yang menjadikan mati dan hidup, supaya Dia menguji kamu, siapa di antara kamu yang lebih baik amalnya. Dan Dia Maha Perkasa lagi Maha Pengampun.” (Qs. AlMulk:2)

Ayat ini dengan jelas mengatakan bahwa kita diciptakan untuk berkompetensi dalam kebaikan baik dalam hal duniawi maupun ukhrawi. Untuk itu seseorang harus senantiasa produktif, karena tanpanya kompetisi itu tidak ada. Selain itu untuk menciptakan budaya kompetensi yang dinamis, maka Islam tidak membatasi produktivitas itu pada satu bidang, namun produktivitas itu digalahkan dalam bidang apapun sepanjang itu dibenarkan oleh syariat.

Dengan adanya produktivitas akan memberikan manfaat kepada orang lain. Artinya, bahwa produktif itu suatu sikap yang ingin terus berkarya atau menghasilkan sesuatu hal yang bermanfaat bagi diri sendiri dan orang lain. Orang yang produktif adalah orang yang tidak menganggur dan tidak pernah berhenti dalam berusaha. Karena di dunia ini banyak aktivitas yang bisa dikerjakan oleh manusia yang dapat mendatangkan banyak manfaat, namun hal itu bisa dilakukan manakala dikerjakan dengan sungguh-sungguh dan diniati dengan baik karena Allah SWT. Rasulullah SAW bersabda:

\section{خير الناس انفعهم للناس (رواه احمد)}

Artinya:

"Sebaik-baik manusia adalah yang paling bermanfaat bagi manusia" (HR. Ahmad)

(Al-Albani. Shahihul Jami'. No. 3289)

Setiap muslim diperintahkan untuk memberikan manfaat bagi orang lain, maka manfaatnya akan kembali untuk kebaikan diri kita sendiri. Allah SWT berfirman:

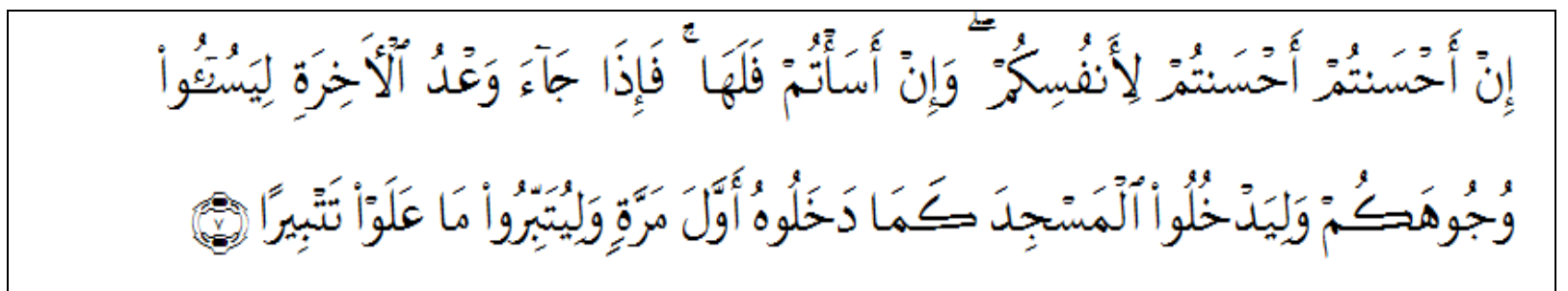

\section{Artinya:}


“Jika kamu berbuat baik (berarti) kamu berbuat baik bagi dirimu sendiri dan jika kamu berbuat jahat, maka (kejahatan) itu bagi dirimu sendiri, dan apabila datang saat hukuman bagi (kejahatan) yang kedua, (kami datangkan orang-orang lain) untuk menyuramkan muka-muka kamu dan mereka masuk ke dalam mesjid, sebagaimana musuhmusuhmu memasukinya pada kali pertama dan untuk membinasakan sehabis-habisnya apa saja yang mereka kuasai." (Qs. Al-Israa:7)

Melihat uraian di atas, maka keberhasilan seorang entepreneur berpusat pada integritas pribadinya, bukan dari eksternalnya, terutama pada orang muslim. Integritas wirausahawan muslim tersebut terlihat dalam sifat-sifatnya, diantaranya taat ibadah, dzikir dan bersyukur, motivasinya bersifat vertikal dan horizontal, niat suci dan ibadah, memandang status dan profesi sebagai amanah, aktualisasi diri untuk melayani, mengembangkan jiwa bebas merdeka, azam bangun lebih pagi, selalu berusaha meningkatkan llmu dan ketrampilan, semangat hijrah, keberanian memulai, memulai usaha dengan modal sendiri walaupun kecil, sesuai bakat, jujur, suka menyambung tali silaturahim, memiliki komitmen pada pemberdayaan dan lain sebagainya (Zahroh, 2014).

\section{Analisa terhadap Membangun Entrepreneurship}

Bekerja merupakan kegiatan yang dilakukan manusia untuk memenuhi kebutuhan hidupnya, sebab bekerja adalah wajib bagi seseorang untuk melakukan perubahan dalam hidupnya, salah satunya bisa dilakukan dengan berwirausaha atau entepreneur. Kewajiban itu lebih disebabkan oleh kebutuhan yang mendesak bagi seseorang untuk keluar dari kelemahan ekonomi sehingga perekonomian menjadi stagnan yang jika dibiarkan akan semakin memburuk.

Kewirausahaan merupakan suatu kemampuan yang penuh semangat dan keberanian guna menciptakan usaha baru atau mengembang usaha yang telah ada secara optimal sehingga mampu memperoleh keuntungan yang lebih besar. Jadi entrepreneurship atau kewirausahaan dalam hal ini erat sekali kaitannya dengan kondisi kejiwaan atau kepribadian seseorang.

Kewirausahaan muncul apabila seorang individu berani mengembangkan usaha dan ide-ide barunya. Proses kewirausahaan meliputi semua fungsi, aktivitas, dan tindakan yang berhubungan dengan perolehan peluang dan penciptaan organisasi usaha. Oleh karena itu, wirausaha adalah orang yang memperoleh peluang dan menciptakan suatu organisasi untuk mengejar peluang itu. Fungsinya adalah memperkenalkan barang baru, melaksanakan metode 
produk baru, membuka pasar baru, membuka bahan/sumber-sumber baru dan pelaksanaan organisasi baru (Mustaqim, 2017).

Membangun entrepreneurship tidak semudah membalikkan telapak tangan. Artinya perlu adanya input proses dan output, hal ini bisa dilakukan manakala dalam membangun entrepreneurship yang baik harus memiliki karakter-karakter yang telah dianalisis di atas. Dengan karakter-karakter tersebut seorang entrepreneur dapat menjalankan usahanya dengan rasa hati yang senang dan riang. Dalam Al-Qur'an selalu menyeru manusia untuk menggunakan waktu dengan cara menginvestasikan dalam hal yang menguntungkan melalui tindakan kerja yang baik (Qs. Al-'Ashr ayat 1-3).

Dalam sebuah hadis dikatakan bahwa tangan di atas lebih baik dari pada tangan di bawah. Lebih baik bekerja, meskipun pekerjaan itu oleh orang-orang dinilai sebagai pekerjaan kasar. Dan sebaik-baiknya hasil adalah yang diperoleh dengan karyanya sendiri. Sebagaimana dijelaskan Al-Nawawi sebagaimana diterjemahkan oleh Ma'mun (2010):

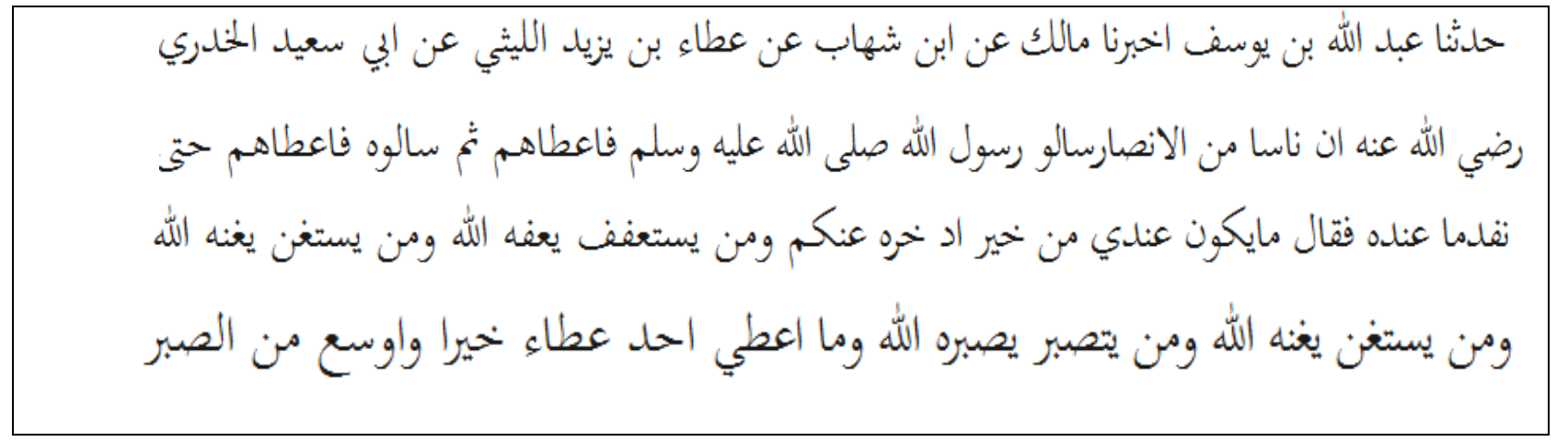

Artinya:

"Abdullah bin Yusuf telah memberitahukan kepada kami, Malik telah mengabarkan kepada kami, dari Syihab dari A'ha bin Yaid Al-Laisi dari Abu Sa'id Al Khudri r.a bahwasannya sekelompok kaum Anshar meminta kepada Rasulullah SAW lalu beliau memberi mereka. Kemudian mereka meminta kepada beliau, maka beliau memberi mereka, kemudian mereka meminta lagi kepada beliau maka beliau memberi mereka lagi. Hingga tidak ada lagi yang tersisa pada beliau. Beliau bersabda: "Harta apapun yang ada padaku, tidak akan aku simpan dari kalian. Barang siapa menahan dirinya untuk tidak memintaminta maka Allah akan memeliharanya darinya. Barang siapa melatih diri untuk bersabar niscaya Allah memberinya kesabaran. Dan tidak ada pemberian yang lebih baik dan lebih luas diberikan kepada seseorang melebihi kesabaran."

Berdasarkan hadis di atas, dapat dipahami bahwa pada setiap orang Islam untuk selalu bekerja dan berjuang, serta melarang segala bentuk praktek kemalasan dan pangku tangan. 
Sehingga dikatakan dengan jelas bahwa barang siapa menahan dirinya untuk tidak memintaminta maka Allah akan memeliharanya darinya.

Islam mengajarkan kepada umatnya untuk menggunakan harta dengan berorientasi pada kebaikan dan manfaat yang optimal, bukan hanya untuk diri sendiri tetapi juga untuk semua manusia, karena dalam Islam sebaik-baik manusia adalah yang bermanfaat bagi manusia yang lain. Sebagaimana sabda Rasulullah SAW:

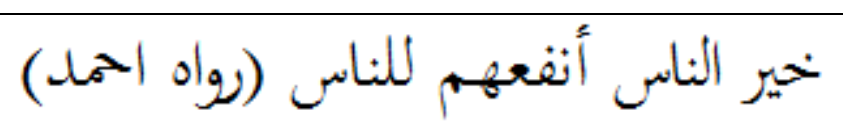

Artinya:

"Sebaik-baik manusia adalah yang paling bermanfaat bagi manusia" (HR. Ahmad)

(Al-Albani. Shahihul Jami’. No. 3289)

Dalam Islam mengajarkan, bahwa pemilik harta yang mutlak adalah Allah (prinsip tauhid), sementara manusia hanyalah pemegang amanah (agent of trust). Islam sangat mengapresiasi orang yang bekerja, manusia tidak akan mendapat apa apa kecuali atas usahanya, dalam sejarah kehidupan Nabi Muhammad SAW juga dikisahkan bahwa beliau terlahir dari keluarga entrepreneur Jiwa kewirausahaan yang ada dalam diri Nabi Muhammad SAW adalah hasil sebuah proses yang panjang, dimulai sejak beliau masi kecil, jauh sebelum diangkat menjadi Nabi dan Rasul, beliau sudah dikenal sebagai pedagang, bahkan beliau dijuluki pedagang yang dapat dipercaya. Hal ini sesuai dengan penelitian yang dilakukan oleh Nurfauzi (2016) mengatakan bahwa terdapat peran yang sangat baik bagi seseorang yang melakukan entrepreneur yaitu meningkatkan produktivitas barang dan jasa, mampu meningkatkan pendapatan perkapita, mendorong inovasi produk baru baik barang atau jasa, mampu menciptakan lapangan kerja, memberikan kemudahan dan kenyamanan, mendorog kemajuan ilmu pengetahuan dan teknologi, serta meningkatkan pendapatan negara dari sektor pajak. Dari hasil penelitian tersebut tercerminkan bahwa begitu pentingnya seseorang untuk membangun entrepreneurship yang mana akan memberikan manfaat kepada dirinya sendiri maupun orang lain dan serta dapat mengajarkan kepada diri seseorang untuk selalu mencari kehidupan yang seimbang antara dunia dan akhirat atau tercapainya tujuan fallah dan maslahah. 


\section{E. KESIMPULAN}

Berdasarkan pemikiran di atas, maka dapat disimpulkan bahwa untuk membangun kewirausahaan dalam perspektif ekonomi syariah adalah menumbuhkan suatu karakter yang disiplin, mandiri, realistis, komitmen, jujur, kreatif dan produktif untuk mewujudkan suatu keuntungan yang dapat membawa keberkahan dan tetap menjalani usahanya dengan memperhatikan kesimbangan kehidupan dunia dan akhirat. Dengan adanya karakter-karakter tersebut akan memberikan dampak pada seorang entrepreneur untuk selalu menjaga usahanya dengan baik dan tidak melakukan suatu kegiatan usaha yang merugikan orang lain, seperti menghancurkan usaha orang lain dengan cara yang bathil. Sehingga nantinya akan mencapai tujuan hidup, yaitu tujuan untuk mencapai fallah dan maslahah. Artinya, seorang entrepreneur memikirkan keberuntungan jangka panjang baik dunia dan akhirat serta tidak memandang material saja tetapi juga menandang spiritual. Dengan demikian, seorang entrepreneur akan merasakan tercapai dan terpenuhinya kebutuhan hidup secara seimbang antara dunia dan akhirat.

Melihat dari pencapaian tujuan di atas, dapat dipahami bahwa terdapat perbedaan antara entrepreneurship konvensional dengan syariah dari berbagai aspek, yaitu: 1) aspek motif, dimana pada pada entrepreneurship konvesional adalah kebutuhan, sedangkan entrepreneurship syariah adalah Al-Qur'an dan As-Sunnah, 2) aspek kepemilikan harta, dimana pada pada entrepreneurship konvesional adalah harta milik individu, sedangkan entrepreneurship syariah adalah harta milik Allah SWT, 3) aspek distribusi, dimana pada pada entrepreneurship konvesional adalah philantropy, sedangkan entrepreneurship syariah adalah infaq fi sabilillah,

Untuk itu, agar spirit Ekonomi Syariah tentang entrepreneurship semakin bisa dipahami dengan baik, maka ke depan perlu terus dilakukan kajian dan penelitian terkait entrepreneurship dalam prespekif Ekonomi Syariah betul-betul diimplementasikan dengan baik di tengah-tengah masyarakatf.

\section{DAFTAR PUSTAKA}

Al-Albani, Muhammad Nashiruddin. Shahihul Jami'. No. 3289.

Al-Nawawi, Imam. 2010. Al-Minhaj Syarh Shahih Muslim ibn Al-Hajjaj, Kitab Zakat, Bab Larangan Meminta-Minta Kepada Orang Lain. Terj. Agus Ma’mun, dkk. Jakarta: Darus Sunnah Press.

Al-Qardhawi, Yusuf. 2019. Norma dan Etika Ekonomi Islam. Jakarta: Gema Insani Press. Al-Qur'an dan Terjemahnya. 2012. Jakarta: Kementerian Agama RI. 
Asmani, Jamal Ma’mur. 2011. Sekolah Entrepreneur. Yogyakarta: Harmoni.

Darwis, Muhammad. 2016. Pendekatan Syariah dalam Upaya Membangun Karakter Jiwa Entrepreneurship. Jurnal Manajemen \& Kewirausahaan. Vol. 1 No. 2 November. 2017. Entrepreneurship dalam Perspektif Islam; Meneguhkan Paradigma Pertautan Agama dengan Ekonomi. Iqtishoduna Vol. 6 No. 1 April.

Desmita. 2011. Psikologi Perkembangan Peserta Didik. Bandung: Remaja Rosda Karya.

Hendro. 2010. Kewirausahaan. Jakarta: Erlangga.

Imron, Ali. 2012. Manajemen Peserta Didik Berbasis Madrasah. Jakarta: Bumi Aksara.

Moleong, Lexy J. 2018. Metode Penelitian Kualitatif. Bandung: Remaja Rosdakarya.

Mustaq, Ahmad. 2010. Etika Bisnis dalam Islam. Jakarta: Pustaka al-Kautsar.

Mustaqim, Yunus. 2017. Spiritual Enterpreneurship dalam Jiwa Perawat. Indonesia Jurnal Perawat Vol. 2 No.2.

Mustari, Mohamad. 2014. Nilai Karakter Refleksi Untuk Pendidikan. Jakarta: Raja Grafindo Slaughter, Michael. 2010. 6 Principles for Risking Renewal Spiritual Entrepreneurs. Nashville: Abingdon Press.

Naim, Ngainun. 2012. Character Building Optimalisasi Peran Pendidikan dalam Pengembangan Ilmu dan Pembentukan Karakter Bangsa. Yogyakarta: Ar-Ruzz Media.

Nurfauzi, Yogi. 2016. Peran Wirausaha Muslim dalam Implementasi Masyarakat Ekonomi ASEAN (MEA). el-Jizya Jurnal Ekonomi Islam, Vol. 4 No. 2, Juli-Desember.

Poerwadarminto. 2011. Kamus Besar Bahasa Indonesia. Jakarta: Balai Pustaka.

Pusat Pengkajian dan Pengembangan Ekonomi Islam (P3EI). 2010. Ekonomi Islam. Jakarta: Rajawali Perss.

Suherman, Eman. 2012. Manajemen Masjid. Bandung: Alfabeta Persada.

Suryana. 2017. Kewirausahaan. Jakarta: Salemba Empat.

Tim Penyusun. 2012. Kamus Besar Bahasa Indonesia. Jakarta: Departemen Pendidikan dan Kebudayaan.

Wiyani, Novan Ardy. 2013. Manajemen Kelas: Teori dan Aplikasinya Untuk Menciptakan Kelas yang Kondusif. Jakarta: Ar-Ruzz Media.

Zahroh, Aminatuz. 2014. Spiritual Entrepreneur. Iqtishoduna Vol. 4 No. 1 April.

Zulfiria dan Arif, Zaenal. 2018. Membangun Kewirausahaan (Entrepreneurship) Qur'ani di Perguruan Tinggi. Rausyan Fikr. Vol. 14 No. 1 Maret. 